\title{
Overexpression of the Lias gene attenuates hepatic steatosis in Leprdb/db mice
}

\author{
Guangcui Xu' ${ }^{1}$, Tingting Yan ${ }^{1}$, Qiang Peng ${ }^{1}$, Haibin $\mathrm{Li}^{1}$, Weidong Wu ${ }^{1}$, Xianwen Yi ${ }^{2}$ and Yingzheng Zhao ${ }^{1}$ \\ 1School of Public Health, Xinxiang Medical University, Xinxiang, Henan Province, China \\ 2Lineberger Comprehensive Cancer Center, University of North Carolina, Chapel Hill, North Carolina, USA
}

Correspondence should be addressed to X Yi or Y Zhao: xyi2000@med.unc.edu or yingzhengzhao@126.com

\begin{abstract}
Oxidative stress is proposed to be involved in nonalcoholic fatty liver disease (NAFLD). However, antioxidant therapy results in controversial outcomes. Therefore, we generated a new antioxidant/NAFLD mouse model, LiasHigh/HighLeprdb/db mice, by crossbreeding Leprdb/db mice, an obesity mouse model, with LiasHigh/High mice, generated by overexpression of lipoic acid synthase gene (Lias) and having increased endogenous antioxidant capacity, to investigate whether the new model could block the development of NAFLD. We have systemically characterized the novel model based on the main features of human NAFLD, determined the impact of enhanced endogenous antioxidant capacity on the retardation of NAFLD and elucidated the underlying mechanisms using various biological and pathological methods. We found that LiasHigh/HighLeprdb/db mice ameliorated many pathological changes of NAFLD compared with the control. In particular, Lias High/HighLLeprab/db mice displayed the improved liver mitochondrial function, reflecting the decline of mitochondrial microvesicular steatosis, and reduced oxidative stress, which mainly contributes to the alleviation of pathologic alterations of the NAFLD progression. Our new model shows that mitochondrial dysfunction is a major pathogenesis for liver steatosis. Overexpression of Lias gene effectively reduces oxidative stress and protects mitochondria, and consequently attenuates NAFLD/NASH.
\end{abstract}

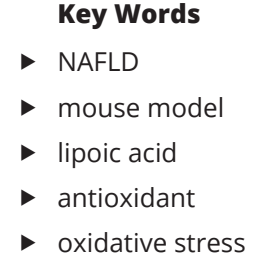

Journal of Endocrinology (2021) 248, 119-131

\section{Introduction}

In association with the obesity pandemic, the prevalence of nonalcoholic fatty liver disease (NAFLD) and its progressive form, nonalcoholic steatohepatitis (Sanyal et al. 2010), is rising in the whole world and is estimated to reach $30 \%$ of all adults in developed countries (Pais et al. 2016, Wong \& Wong 2016, Younossi et al. 2016). To date, the pathogenic mechanism of NAFLD/NASH has not been fully clarified. Therefore, none of drugs has been approved by FDA for NAFLD/NASH so far (Filozof et al. 2015).

According to the 'two-hit theory', oxidative stress is regarded as the 'second hit' that is required for the development of NAFLD (Day \& James 1998). Antioxidant therapy should represent a logical therapeutic strategy for the treatment of NAFLD. However, antioxidant therapies have produced controversial results in clinical trials (Singal et al. 2011). For example, vitamin E supplementation prevents fibrogenesis, reduces fatty liver and inflammation in NAFLD/NASH (Vajro et al. 2004, Caldwell \& Lackner 2017). N-acetylcysteine (NAC) found improvement in liver enzymes in patients with NASH (Pamuk \& Sonsuz 2003). On the other hand, other studies using vitamin $E$ failed to show any beneficial effect on ALT, or liver fibrosis (Groenbaek et al. 2006, Sanyal et al. 2010). 
The study of human NAFLD is hampered by the slow development of the disease. Thus, mouse models are indispensable tools to elucidate pathogenic mechanisms, not only to evaluate the pathogenesis and progression of NAFLD, and but test the therapeutic effects of various potential drugs. Until now, none of antioxidant/NAFLD model is available. To fill this gap, we have generated a unique antioxidant-NAFLD mouse model by mating Lias High/High antioxidant mouse model with Leprdb/db mice. $L e p r d b / d b$ mice have a defect in leptin receptor and generate many of the metabolic disturbances present in NAFLD patients (Solis-Munoz et al. 2011). The $d b / d b$ animals are obese, present insulin resistance or diabetes, and develop hepatic steatosis. In addition, they may develop NASH after a second stimulus such as the intake of transfat or a methionine and choline-deficient (MCD) diet. When $d b / d b$ mice are fed a MCD diet, they can develop significant liver fibrosis (Sahai et al. 2004, Wortham et al. 2008). It is possible that oxidative stress may serve as a second stimulus for the development of NAFLD into NASH. The phenotype of the $d b / d b$ mice better simulates the condition of human metabolic syndrome in many circumstances. However, these mice are limited because they do not spontaneously develop liver fibrosis or NASH without a second stimulus (Takahashi 2012, Ka et al. 2017). It is possible that oxidative stress can work as the second stimulus to induce inflammation and/or liver fibrosis. It is well-known that mitochondria are the major cellular source of reactive oxygen species (Lindquist et al. 2018) and are the most immediate target of ROS. We postulated that excess ROS mainly produced from mitochondrial dysfunction due to a defective cellular antioxidant systems led to the 'second hit' for the development of NAFLD. We selected Lias mice for the creation of an antioxidant mouse model according to our hypothesis and several unique features of $\alpha$-lipoic acid (LA) (Yi \& Maeda 2005, Liu 2008, Tanaka et al. 2015, Namazi et al. 2018).

Lipoic acid (LA) is the product of lipoic acid synthetase (Lias) and a strong antioxidant. It is also a coenzyme of two enzymes (pyruvate dehydrogenase complex and $\alpha$-ketoglutarate dehydrogenase complex) involved in energy metabolism in mitochondria (Dorsam \& Fahrer 2016). LA plays an important role in the antioxidant defense system of the body. LA has the unique characteristics. For example, it can eliminate various free radicals in the body, enhance the antioxidant capacity through transcriptional regulation, possibly protect mitoquinone (MitoQ10) and recycle other antioxidants such as vitamin C and E, MitoQ10 and glutathione. The elimination of Lias gene will lead to the embryo stop development, indicating that endogenous LA plays an irreplaceable role in antioxidant activity and energy regulation (Yi \& Maeda 2005). Previous studies have repeatedly proved that both exogenous and endogenous lipoic acids significantly changed the level of antioxidation and the development of atherosclerosis (Yi \& Maeda 2006, Yi et al. 2012).

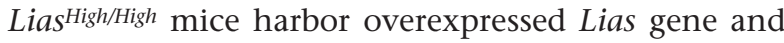
the genetic engineering strategy of Lias ${ }^{H i g h / H i g h}$ mice was based on genetic modification of the 3'-UTR of lipoic acid synthase (Lias) mRNA (Park et al. 2008, Xu et al. 2016). The Western blot result confirmed significantly increased Lias protein expression in Lias ${ }^{\mathrm{High} / \mathrm{High}}$ mice $(\sim 160 \%$ of Lias gene expression), accompanied by correspondingly increased antioxidant capacity and decreased oxidative stress compared to WT and consequently affects the development of these diseases (Xu et al. 2016) In this study, we characterized the antioxidant/NAFLD model, and showed that overexpression of Lias gene increased mitochondrial antioxidant capacity and improved NAFLD in Lias $^{H i g h / H i g h}$ Lepr $^{\text {db/db }}$ mice.

\section{Materials and methods}

\section{Animals}

Leprdb/+ heterozygous mice with the C57B6/J background were purchased from the Jackson Laboratory (Stock number: 000697, Bar Harbor). Animal experiments were performed in accordance with the guidelines of the Institutional Animal Care and Use Committee of Xinxiang Medical University (protocol number XYLL2017086, approved 3 March 2017).

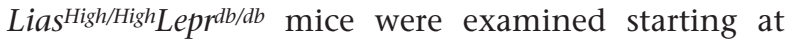
4 weeks of age. Age- and sex-matched Lias $^{+/+}$Lepr $^{d b / d b}$ littermates served as controls. There were a total of 10 male and 7-9 female mice per group. All animals were fed a normal chow (produced according to NIH-07 standard and meet the hygienic standard of experimental animal compound feed (GB 14924.2)) with $4 \%$ fat and $20.5 \%$ protein content (Puluteng Inc. Shanghai, China). Water was provided ad libitum. The mice were housed in a $12 \mathrm{~h}$ light: $12 \mathrm{~h}$ darkness cycle with ambient room temperatures of $20-25^{\circ} \mathrm{C}$ and relative humidity of $60-70 \%$. At the 28 th week, the mice were sacrificed after anesthetized with isoflurane. The blood was collected from the femoral artery and the livers were separated from the animal for weighing. A portion of the liver was fixed in $4 \%$ paraformaldehyde for histological evaluation. 
The plasma and liver samples were stored at $-80^{\circ} \mathrm{C}$ until they were examined.

\section{Genotyping by TaqMan probe fluorescence quantitative PCR}

The Leprdb/db mouse has a $\mathrm{G} \rightarrow \mathrm{T}$ point mutation in the leptin receptor gene. Because homozygous mice are infertile, efficient maintenance of this strain requires an accurate genotyping strategy to detect heterozygotes. However, commonly used methods are time-consuming and unstable with the requirement of restriction enzyme digestion. Thus, we adapted a new method to efficiently identify the genotype. In brief, SNP database website (http://www.ncbi.nlm.nih.gov/snp), Leprdb/+ gene sequence (gene sequence number rs1801133) and SNP locus information were obtained from NCBI. TaqMan probes and primers were designed using Premier 6 software and Primer Express 3, respectively. TaqMan probes were labeled with FAM or HEX fluorescein. The probes and primers were synthesized by Shanghai Biotechnology Co., Ltd. The sequence of primers: 5'-ACCAACTTCCCAA CAGTCCA-3' and 5'-TGATGCCCTGAAAATCAAGC-3'; Probes for screening WT: HEX-5'-TTT GATGGAGGGAAA CAAACCTA-BHQ-X-3', and for $d b$ mutant FAM-5'-TT TTGATGGAGGTAAACAAACCTA A-BHQ-X-3'. Genomic DNA was isolated from mouse tail clips. PCR reactions were performed on a Roche LC480 (Roche Diagnostics). Initial denaturation was $95^{\circ} \mathrm{C}$ for $1 \mathrm{~min}$, then 40 cycles of 3 steps: $95^{\circ} \mathrm{C}$ for $15 \mathrm{~s}, 60^{\circ} \mathrm{C}$ for $40 \mathrm{~s}$.

\section{Body weight, food intake and blood glucose}

Food intake, body weight and blood glucose were monitored monthly from 1 to 7 months. Blood glucose measurement and body weight were conducted between 15:00 and 16:00 $\mathrm{h}$ after $5 \mathrm{~h}$ of fasting. Blood glucose was sampled from tail tipping and measured on OneTouch Verio Flex ${ }^{\mathrm{TM}}$ meter (Johnson-Johnson). For HbA1c, the mice were anesthetized with isoflurane, blood was collected from the femoral artery, HbA1c, was measured at the 7th month by latex agglutination test using the automatic biochemical analyzer (ADVIA 2400, Siemens, Germany).

Intraperitoneal glucose tolerance test (IPGTT), insulin tolerance test (ITT) and pyruvate tolerance test (PTT)

For the IPGTT, all mice were fasted for $16 \mathrm{~h}$ with free access to water before intraperitoneal injection of a glucose solution $(0.5 \mathrm{mg} / \mathrm{kg}$ of body wt) from 1 to 7 months. At the 7th month, all mice were fasted for $6 \mathrm{~h}$ prior to intraperitoneally injection of human biosynthetic insulin ( 1 units $/ \mathrm{kg}$ of body wt) or sodium pyruvate $(1 \mathrm{~g} / \mathrm{kg}$ of body wt), respectively. Blood was obtained from the tail via a tail tip excision, and blood glucose measured by the glucometer at designed time points.

\section{Measurement of plasma and hepatic biochemistry}

The plasma alanine aminotransferase (ALT), glutamicoxaloacetic transaminase (Mansouri et al. 1997) activities, total superoxide dismutase (SOD) and triglycerides (TG), total cholesterol (CHO), high-density lipoprotein (HDL), low-density lipoprotein (LDL) and non-esterified free fatty acid (NEFA) concentrations were measured using commercial kits following the manufacturer's instructions (Jian-Cheng Bioengineering Incorporated Company Ltd. Nan Jing, China). Levels of ATP of the hepatic samples were measured using assay kits (Beyotime Bioengineering Incorporated Company Ltd. Shanghai, China) according to manufacturer's instructions. Total liver lipids were extracted following Folch's method (Folch et al. 1957). Liver TG and $\mathrm{CHO}$ concentrations were determined using the same kits used for serum samples.

\section{Plasma and hepatic mitochondrial oxidative stress}

Liver samples were flash-frozen and ground in liquid nitrogen. Ground tissue was homogenized on ice in PBS pH 7.4. The hepatic mitochondria were separated for the homogenate using differential centrifugation. This method was performed according to the protocol described by Rogers et al. (2011). Briefly, 500 mg liver tissue was washed and minced in PBS supplemented with $10 \mathrm{mM}$ EDTA at $4^{\circ} \mathrm{C}$. The tissue was homogenized with ten strokes with a glass homogenizer at $800 \boldsymbol{g}$ in PBS buffer $(\mathrm{pH} 7.2)$ at $4^{\circ} \mathrm{C}$, supplemented with PMSF and protease inhibitor cocktail (Thermo Fisher Scientific). The cell debris were removed by centrifugation at $1000 \boldsymbol{g}$ for $5 \mathrm{~min}$. Mitochondria were then isolated from the supernatant by centrifugation at $11,000 \boldsymbol{g}$ for $10 \mathrm{~min}$ at $4^{\circ} \mathrm{C}$. The final mitochondrial pellet was washed in MSHEB buffer and after another similar centrifugation step, was resuspended in a minimal volume of PBS buffer.

Thelevelsofsuperoxidedismutase2(SOD2), glutathione (GSH), malondialdehyde (MDA) and total antioxidation capacity (T-AOC) in the mitochondria and plasma were measured using commercial kits following manufacturer's instructions (Cell Biolabs, Inc., San Diego, CA, USA). Protein content was determined using the BCA method 
(Thermo Scientific). Enzyme activity units $(\mathrm{nmol} / \mathrm{mL})$ were normalized to protein concentration.

\section{Liver ROS examination}

The content of ROS in liver homogenate was determined by DCF fluorescence. The liver homogenate was diluted 100 times with PBS to make the cell suspension. The contents of ROS in different groups were measured by using the DCFH-DA detection kit (Beyotime Biotechnology, Shanghai, China) according to the manufacturer's instruction. The cells were incubated with DCFH-DA in the dark for $30 \mathrm{~min}$ at $37^{\circ} \mathrm{C}$. After washed, Fluorescence intensity of the liver was detected at the condition of 488 $\mathrm{nm}$ excitation wavelength, $525 \mathrm{~nm}$ emission wavelength by using an enzyme labeling instrument (EnSpire Multimode Plate Reader, Perkin Elmer).

\section{Serum cytokine measurement}

Serum levels of IL1 $\beta$, IL6, TNF $\alpha$ and monocyte chemoattractant protein-1 (MCP1) concentrations were determined using ELISA kits (Beijing Dingguo Biotechnology Co. Ltd, Beijing, China). Each assay was carried out in duplicate. Absorbance was measured at 450 $\mathrm{nm}$ by means of a spectrophotometer (EnSpire Multimode Plate Reader, Perkin Elmer).

\section{Liver histologic examination}

The samples from the mouse liver were collected and fixed in $4 \%$ paraformaldehyde for $24 \mathrm{~h}$. Fixed tissue was embedded in paraffin. Sections ( $4 \mu \mathrm{m}$ in thickness) were cut and processed by graded-alcohol dehydration, cleared in xylene, mounted and stained with H\&E, and Masson Trichrome to evaluate the extent of hepatosteatosis, inflammation and fibrosis.

The degree of hepatosteatosis was semi-quantitatively evaluated using the scoring system recommended by the Pathology Committee of the Nonalcoholic Steatohepatitis Clinical Research Network (NSCRN) (Brunt et al. 1999, Franzen et al. 2005). Sixteen slides of mouse livers covering the whole spectrum of NAFLD, were blindly evaluated by an experienced animal pathologist in a blinded fashion.

The scoring system included semi-quantitative evaluation of three parameters: area of steatosis $(0 \leq 5 \%$, $1=5-33 \%, 2=33-66 \%, 3 \geq 66 \%$ ), distribution of steatosis $(0=$ zone $3,1=$ zone $1,2=$ azonal, $3=$ panacinar $)$, and the presence/absence of microvesicular steatosis $(0=a b s e n t$,
$1=$ present) (Kleiner et al. 2005). The difference between macrovesicular and microvesicular steatosis was defined by whether the vacuoles displaced the nucleus to the side (macrovesicular) or not (microvesicular).

\section{Transmission electron microscopy (TEM)}

After sacrificing the mice, livers were immediately cut into small pieces, fixed in PBS-buffered $(\mathrm{pH} 7.4) 2.5 \%$ glutaraldehyde for $4 \mathrm{~h}$ at room temperature (RT), and post-fixed in $1 \%$ buffered osmium tetroxide for $1 \mathrm{~h}$ at RT, dehydrated in a series of graded ethanol solution. The tissues were embedded in Epon 812 resin and placed in a $70^{\circ} \mathrm{C}$ oven for $72 \mathrm{~h}$. The resin blocks were thick-sectioned, stained with $1 \%$ Toluidine blue and examined by light microscopy. One block each from Zone 1 (periportal) and Zone 3 (centrilobular) of the liver was chosen for each animal. The chosen blocks were ultrathin-sectioned (70 $\mathrm{nm})$, placed on formvar-coated copper grids and stained with uranyl acetate and lead citrate. The grids were examined on a Hitachi H-7500 transmission electron microscope. For measurement of mitochondrial size, total of 150 mitochondria were randomly selected from 10 micrographs at 25,000× magnification per group. Quantitative morphometric analysis using NIH Imaging Software was performed by a histologist blinded to the sample genotypes.

\section{Western blotting analysis}

Total proteins were extracted from the hepatic tissue or their mitochondria. Protein concentration was determined using a protein assay reagent (Bio-Rad Laboratories). Equal amounts of total protein were resolved by $10-12 \%$ SD-PAGE and transferred to a polyvinylidene difluoride membrane. They were then incubated with the following primary antibodies: LIAS (1:1000, Proteintech, USA), SREBP1 (1:1000, Cell Signaling), FAS (1:1000, Cell Signaling), PGC1 $\alpha$ (1:800, Affinity Biosciences, Cincinnati, $\mathrm{OH}, \mathrm{USA})$, for $2 \mathrm{~h}$. The membranes were subsequently washed in TBS containing $0.1 \%$ Tween 20 and incubated with horseradish peroxidase-conjugated anti-rabbit secondary antibodies (1:3000, Earthox, San Francisco, CA, USA) for $1 \mathrm{~h}$ at room temperature. Immunoreactive bands were visualized using the Amersham ECL Prime Western Blotting Detection Reagent with enhanced chemiluminscence (GE Healthcare Bio-Sciences) and exposed to ECL Hyperfilm (GE Healthcare Bio-Sciences). Membranes were incubated with rabbit polyclonal https://joe.bioscientifica.com https://doi.org/10.1530/JOE-19-0606 (c) 2021 Society for Endocrinology Published by Bioscientifica Ltd.
Printed in Great Britain 
Table 1 Gene name and GenBank accession number used in quantitative reverse transcriptase PCR.

\begin{tabular}{|c|c|c|c|}
\hline Gene & Accession No. & Gene name & Function \\
\hline Ucp2 & NM-011671.5 & Uncoupling protein 2 & Energy expenditure \\
\hline Acads & NM-007383.3 & $\begin{array}{l}\text { Acyl-Coenzyme A } \\
\text { dehydrogenase, short chain }\end{array}$ & Mitochondrial $\beta$-oxidation \\
\hline Cpt1a & NM-013495.2 & $\begin{array}{l}\text { Carnitine } \\
\text { palmitoyltransferase } 1 \mathrm{a}\end{array}$ & Mitochondrial $\beta$-oxidation \\
\hline Tfam & NM-009360.4 & $\begin{array}{l}\text { Mitochondrial transcription } \\
\text { factor A }\end{array}$ & Mitochondrial biogenesis \\
\hline Sirt1 & NM-01159589.2 & Sirtuin 1 & Insulin sensitivity \\
\hline Prkaa2 & NM-01356568.1 & $\begin{array}{l}\text { protein kinase, AMP-activated, } \\
\text { alpha } 2 \text { catalytic subunit }\end{array}$ & Regulating cellular energy \\
\hline
\end{tabular}

\begin{tabular}{l}
\hline Primer sequence \\
\hline 5'-CTCTACGACTCTGTCAAACAGT-3' \\
5'-GGACCTTTACCACATCTGTAGG-3' \\
5'-AGTTCAAGCTGGCAGACATGGC-3' \\
5'-CCTGGTGGCTAATGGCGGTTG-3' \\
5'-CTACATCACCCCAACCCATATT-3' \\
5'-GATCCCAGAAGACGAATAGGTT-3' \\
5'-GTGAGCAAGTATAAAGAGCAGC-3' \\
5'-CTGAACGAGGTCTTTTTGGTTT-3' \\
5'-CGCTGTGGCAGATTGTTATTAA-3' \\
5'-TTGATCTGAAGTCAGGAATCCC-3' \\
5'-CGATGAGGCTGTGAAGGAAGTCTG-3' \\
5'-GGAGGACTAGAGGCGAGGTAGAAC-3'
\end{tabular}

anti-GAPDH antibodies (1:5000, Proteintech) or antiCOXIV antibodies (1:5000, Proteintech) to serve as controls for equal loading. All Western blot analyses were performed at least three times. The density of proteins in each band was determined using image J2X software and expressed as relative to the density of the corresponding band of the control protein immunoblot.

\section{Quantitative real-time PCR (qRT-PCR)}

Total RNA was isolated from Lias High/High Leprdb/db and

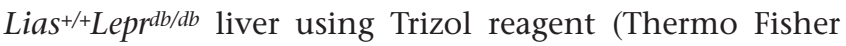
Scientific) and according to the manufacturer's instructions. RNA concentrations were determined by Nanodrop 1000 (Thermo Fisher Scientific). Five micrograms of RNA were reverse-transcribed to cDNA using the M-MLV kit (Thermo Fisher Scientific) following the instructions. The primer sequences used for the amplification of the indicated genes are listed in Table 1. Amplification and detection of specific products were performed using the LightCycler® 96 (Roche Diagnostics). All the samples were analyzed in duplicate. Cq values were generated by the Roche software. Non-obese Lias $^{+/+}$Lepr $^{d b /+}$ mice as control. Fold changes were calculated by the $2^{-\Delta \Delta \mathrm{Cq}}$ method. $\beta$-actin was used as housekeeping gene for mRNA.

\section{Quantification of mitochondrial DNA content}

Mitochondrial DNA (mtDNA) content was quantified by real-time fluorescent quantitative PCR. Liver tissue from Lias $^{H i g h / H i g h} L_{e p r}{ }^{d b / d b}$ and Lias ${ }^{+/+}$Lepr $^{d b / d b}$ mice was grinded, then added nucleic acid extract solution for the extraction of DNA. Mouse nuclear 18S rRNA was used as the internal control. The ratio of the expression of the target gene was got. The primers for detecting the cytochrome b gene of the murine mitochondrial genome were from the GenBank nucleotide sequences.

\begin{tabular}{|lr} 
https://joe.bioscientifica.com & (c) 2021 Society for Endocrinology \\
https://doi.org/10.1530/JOE-19-0606 & Published by Bioscientifica Ltd. \\
Printed in Great Britain
\end{tabular}

\section{Statistical analysis}

Data are expressed as the means \pm S.E.M. Statistical analysis was performed with one-way ANOVA. $P<0.05$ values were considered to be statistically significant. Effects of the dynamic changes of body weight and food consumption were assessed at various time points by multiple ANOVA for each mouse.

\section{Results}

Please note that all outliers have been included, which may be the result of inherent data variability.

\section{Characterizations of Lias High/High Leprdb/db and Lias $^{+/+}$Leprdb/db mice}

Figure 1 reveals that our genotyping approach clearly identified $L e p r$ db/db mouse genotypes for monitoring characterizations of $L e p r d b /+$ mice and Leprdb/db mice. Figure 2A shows that Lias ${ }^{H i g h / H i g h} L e p r d b / d b$ mice displayed significantly higher body weights, compared with Lias $^{+/+}{ }^{2}$ epr ${ }^{d b / d b}$ counterparts since the age of 2 months. Interestingly, after 3 months, the amount of food intake in male Lias ${ }^{H i g h / H i g h} L e p r^{d b / d b}$ was less than male Lias ${ }^{+/+}$Lepr $^{d b / d b}$ mice (Fig. 2B), but their net body weight gain was higher than Lias ${ }^{+/+}$Leprdb/db mice at 2 and 4 months (Fig. 2C). Females showed a similar tendency (Supplementary Fig. $1 \mathrm{~A}$, see section on supplementary materials given at the end of this article). The data suggest that Lias ${ }^{H i g h / H i g h} L e p r d b / d b$ mice utilized food for energy production more efficiently.

\section{Changes of blood carbohydrate and lipid profiles}

To investigate potential liver protection by overexpression of Lias gene, we examined dynamic changes of plasma 


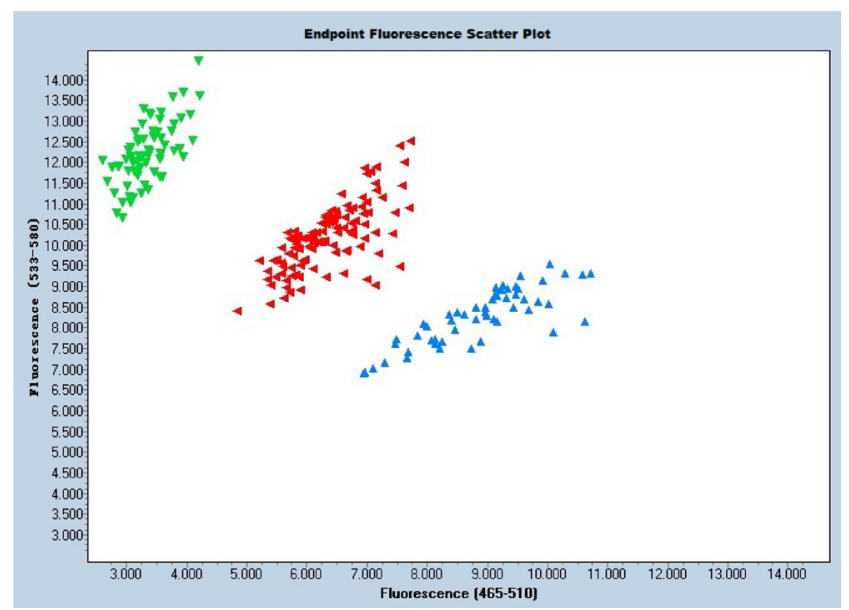

Figure 1

Identification of the Leprdb/db mouse genotype. The Endpoint Fluorescent Scatter Plot shows allele distribution for identification of Leprdb/db mouse genotype. Abscissa indicates FAM signal intensity value and ordinate represents HEX signal intensity value; Blue triangles, WT; Green, homozygote, and Red, heterozygote.

TG, $\mathrm{CHO}$ and glucose concentrations in the mice. Both male (Fig. 2D) and female (Supplementary Fig. 1C)

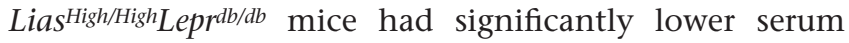
levels of TG than Lias $^{+/+}$Lepr $^{\text {db/db }}$ mice after 3 months of age, especially female mice. Plasma $\mathrm{CHO}$ concentration

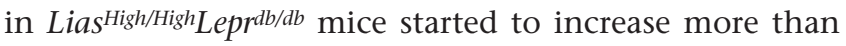

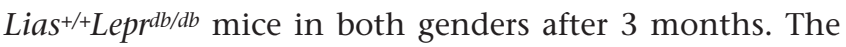
divergence became larger with aging until the mice were sacrificed at 7 months of age (Fig. 2E and Supplementary Fig. 1D). However, plasma LDL levels did not significantly increase, and importantly, HDL concentration significantly increased in Lias ${ }^{H i g h / H i g h} L$ eprdb/db mice (Table 2). The elevated levels of HDL would lead to more cholesterol from the blood and peripheral tissue to the liver for clearance. HDL may be boosted by the elevated endogenous LA since mounting evidence indicated that HDL itself was also an antioxidant (deGoma et al. 2008). In addition,

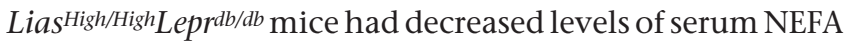
and liver TG compared with Lias $^{+/+}$Leprdb/db counterpart at 7 months of age (Fig. 2M and O). Lias High/High Leprdb/db mice had increased of liver weight compared with $\mathrm{Lias}^{+/+} \mathrm{Lepr}^{\mathrm{db} / d b}$ counterpart at 7 months of age (Fig. $2 \mathrm{~N}$ ). Taken together, these data suggested that enhanced antioxidant content could mitigate lipid disorders.

Liver insulin resistant can result in glucose overproduction (Yki-Jarvinen 2014). Thus, we investigated impact of strengthened endogenous antioxidant reservoir on glucose metabolism and insulin resistance during NAFLD. Plasma glucose level became significantly lower in Lias ${ }^{\text {High/High }}$ Leprdb/db $^{\text {mice compared }}$ with those in Lias $^{+/}{ }^{-L e p r}{ }^{d b / d b}$ mice after 4 months of age (Fig. 2F and Supplementary Fig. 1B). Because $\mathrm{HbA}_{1 \mathrm{c}}$ remains significantly and independently associated with steatosis (Cosma et al. 2015), we measured plasma HbA1c concentration. The data showed that HbA1c level was significantly decreased at 7 months of age in

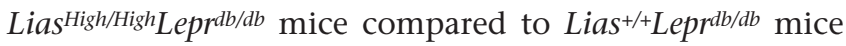
(Fig. 2K). Next, we performed IPGTT. As expected, male

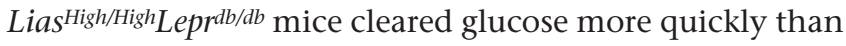

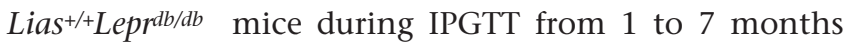
(Fig. 2G, H and Supplementary Fig. 2), suggesting that bolstered endogenous antioxidant capacity abated peripheral insulin resistance. To distinguish whether the decreased insulin resistance in Lias ${ }^{H i g h / H i g h}$ Lepr $^{\text {db/db }}$ mice was resulted from increased absolute insulin production, we measured serum insulin in the male mice. Our results revealed that insulin value was significantly declined in 7-month-old Lias High/High Leprib/db mice than their counterparts (Fig. 2L). At the 7th month, insulin resistance was examined using the ITT method. The results showed a significant reduction in blood glucose levels in ${\text { Lias }{ }^{H i g h / H i g h} L e p r d b / d b}$ mice compared to the

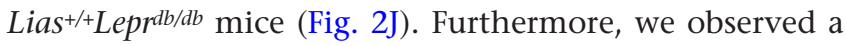
profound effect on the tolerance of both $\mathrm{Lias}^{+/+} \mathrm{Leprdb} / \mathrm{db}$ and Lias ${ }^{H i g h / H i g h} L e p r^{d b / d b}$ mice to a challenge of pyruvate, a major substrate for hepatic gluconeogenesis, as Lias ${ }^{H i g h / H i g h} \mathrm{Lepr}^{\mathrm{db} / \mathrm{d} b}$ mice displayed significantly reduced plasma glucose levels following pyruvate challenge (Fig. 2I). The data clearly indicated that hyperinsulinemia resulting from insulin resistance diminished in Lias ${ }^{H i g h / H i g h} L e p r d b / d b$ mice compared to Lias $^{+/+}$Leprab/db mice.

\section{Plasma and liver mitochondria oxidative stress}

To evaluate hepatic oxidative stress and antioxidant defense status, we measured the SOD2, T-AOC and MDA in plasma (Table 2), and these parameters and GSH in liver mitochondria (Table 3). The results indicated that significantly higher antioxidant/lower oxidative stress levels were observed in Lias ${ }^{H i g h / H i g h}$ Leprib/db $^{\text {compared to }}$ $\mathrm{Lias}^{+/+} \mathrm{Lepr}^{\mathrm{db} / \mathrm{db}}$ mice. Mitochondrial abnormalities leading to decreased ATP production were observed in NASH patients (Caldwell et al. 1999, Cortez-Pinto et al. 1999a,b) and animals (Serviddio et al. 2008). To explore whether elevated endogenous antioxidant reservoir could protect liver mitochondria and thus retain energy homeostasis, we examined ATP yield in liver mitochondria isolated from males. Our result revealed that ATP production was significantly higher in Lias ${ }^{H i g h / H i g h} L_{e p r}{ }^{\text {db/db }}$ than

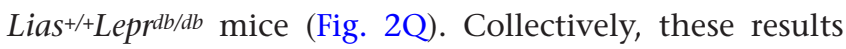



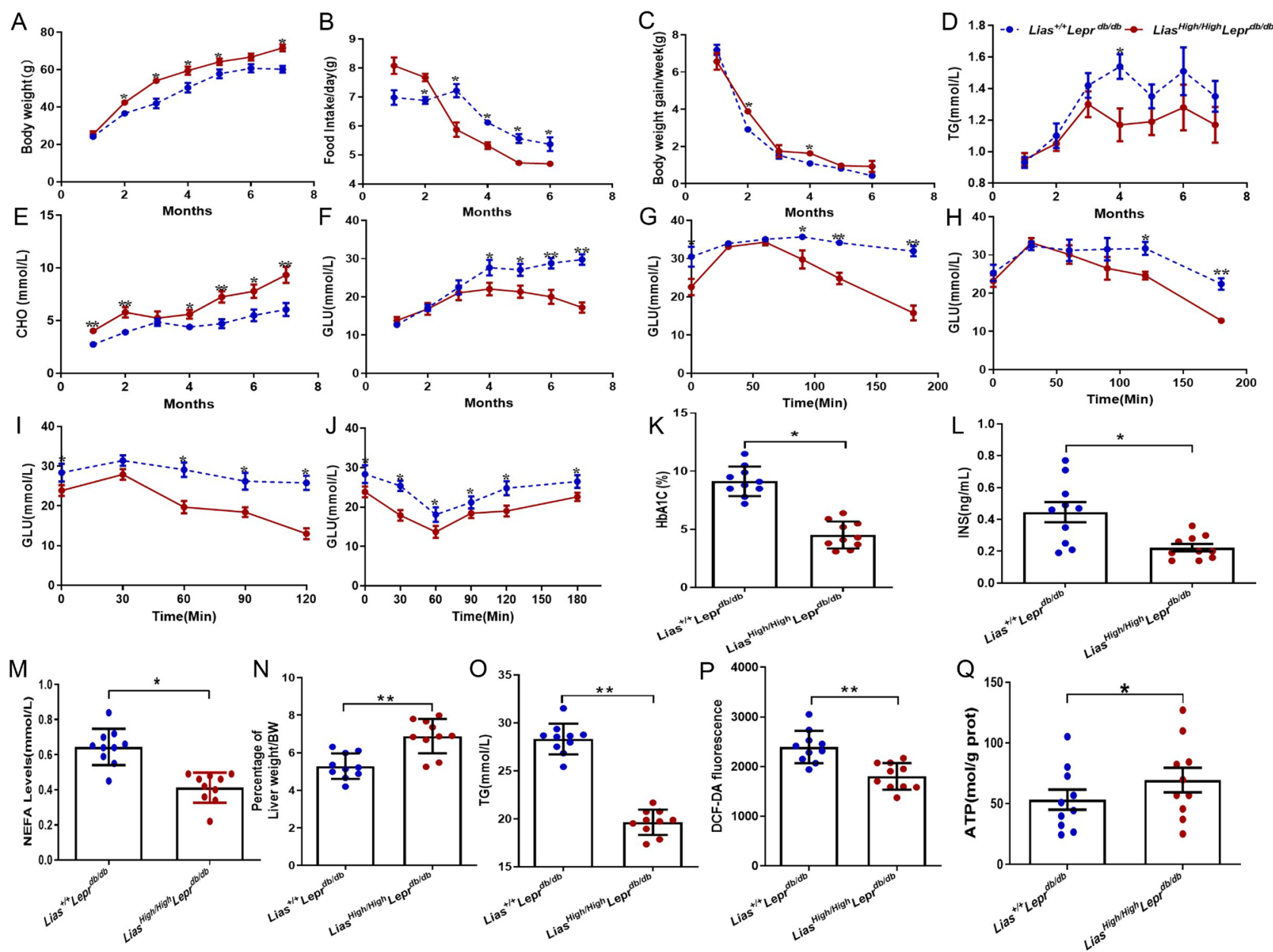

Figure 2

Body weight, food consumption, plasma lipid and glucose levels in Lias High/High Leprdb/db mice (close symbols) and Lias ${ }^{+/+}$Leprdb/db mice (open symbols). The body weight profile in (A) body weight, (B) the amount of food intake, and (C) the net gain of body weight in male mice. Dynamical changes of plasma triglyceride levels (D), and cholesterol concentrations (E), and plasma glucose levels (F), and intraperitoneal glucose tolerance test (IPGTT) (G) at 5 months of age and $(\mathrm{H})$ at 6 months of age, and insulin tolerance test (ITT) (I) and pyruvate tolerance test $(\mathrm{J})$ at 7 months of age. Plasma $\mathrm{HbA} 1 \mathrm{c}$ concentrations (K), insulin concentrations (L), NEFA concentrations (M) at 7 months of age. Liver weight (N), liver triglyceride levels (O), liver ROS levels (P), liver mitochondrial ATP levels (Q) at 7 months old. Data are the means \pm S.E.M. $* P<0.05 ; * \star P<0.01$. A full color version of this figure is available at https://doi.org/10.1530/ JOE-19-0606.

Table 2 Biochemical parameters in LiasHigh/High Leprdb/db and Lias ${ }^{+/+}$Leprdb/db mice. $^{2}$

\begin{tabular}{l}
\hline \\
\hline $\operatorname{LDL}(\mathrm{mmol} / \mathrm{L})$ \\
HDL $(\mathrm{mmol} / \mathrm{L})$ \\
ALT $(\mathrm{U} / \mathrm{L})$ \\
$\mathrm{GOT}(\mathrm{U} / \mathrm{L})$ \\
SOD $(\mathrm{U} / \mathrm{mL})$ \\
MDA $(\mathrm{nmol} / \mathrm{L})$ \\
T-AOC $(\mu \mathrm{M} C R E / \mathrm{mL})$ \\
IL1 $\beta(\mathrm{ng} / \mathrm{L})$ \\
IL6 $(\mathrm{ng} / \mathrm{L})$ \\
TNF $\alpha(\mathrm{ng} / \mathrm{L})$ \\
MCP1 $(\mathrm{ng} / \mathrm{L})$ \\
\hline
\end{tabular}

\begin{tabular}{c}
\hline Lias $^{+/+}$Leprdb/db \\
\hline $2.34 \pm 1.48$ \\
$5.02 \pm 1.81$ \\
$53.01 \pm 18.94$ \\
$28.94 \pm 7.46$ \\
$64.56 \pm 10.97$ \\
$13.57 \pm 3.93$ \\
$504.56 \pm 6.66$ \\
$146.51 \pm 43.67$ \\
$68.45 \pm 21.60$ \\
$1691.92 \pm 65.86$ \\
$232.18 \pm 6.69$ \\
\hline
\end{tabular}

\begin{tabular}{c}
\hline Lias High/High Leprdb/db $^{-1}$ \\
\hline $3.41 \pm 1.42$ \\
$7.69 \pm 1.33$ \\
$34.48 \pm 10.52$ \\
$18.91 \pm 3.14$ \\
$72.71 \pm 8.30$ \\
$9.99 \pm 2.86$ \\
$556.55 \pm 6.84$ \\
$84.15 \pm 25.31$ \\
$58.37 \pm 20.74$ \\
$1104.37 \pm 69.01$ \\
$159.29 \pm 7.92$ \\
\hline
\end{tabular}

\begin{tabular}{c}
\hline P value \\
\hline 0.118 \\
$\mathbf{0 . 0 0 1}$ \\
$\mathbf{0 . 0 4 2}$ \\
0.053 \\
$\mathbf{0 . 0 4 7}$ \\
$\mathbf{0 . 0 4 0}$ \\
$\mathbf{0 . 0 0 1}$ \\
$\mathbf{0 . 0 0 1}$ \\
0.301 \\
$\mathbf{0 . 0 1 8}$ \\
$\mathbf{0 . 0 0 3}$ \\
\hline
\end{tabular}

All mice were male at 7 months of age. Data are represented as mean \pm S.E.M. $(n=10)$. Bold indicates $\mathrm{P}<0.05$.

https://joe.bioscientifica.com

https://doi.org/10.1530/JOE-19-0606 (c) 2021 Society for Endocrinology Published by Bioscientifica Ltd.
Printed in Great Britain 
Table 3 Liver mitochondria oxidative stress in LiasHigh/High Leprdb/db and Lias ${ }^{+/+L e p r d b / d b}$ mice.

\begin{tabular}{|c|c|}
\hline & $\operatorname{Lias}^{+/+} \operatorname{Lepr}^{d b / d b}$ \\
\hline SOD2 (U/mgprot) & $24.09 \pm 2.90$ \\
\hline GSH ( $\mu \mathrm{g} / \mathrm{mgprot})$ & $196.11 \pm 6.12$ \\
\hline MDA (nmol/mgprot) & $5.26 \pm 0.77$ \\
\hline T-AOC (mM CRE/mgprot) & $4.89 \pm 0.15$ \\
\hline
\end{tabular}

\begin{tabular}{c}
\hline Lias High/HighLeprdb/db $^{\text {dis }}$ \\
\hline $30.94 \pm 1.72$ \\
$268.92 \pm 6.83$ \\
$0.92 \pm 0.31$ \\
$5.74 \pm 0.16$
\end{tabular}

\begin{tabular}{c}
\hline P value \\
\hline 0.048 \\
0.001 \\
0.001 \\
0.001
\end{tabular}

All mice were male at 7 months of age. Data are represented as mean \pm s.E.M. $(n=10)$. Bold indicates $\mathrm{P}<0.05$.

suggested that energy homeostasis was retained in Lias High/HighLeprdb/db mice during NAFLD likely due to mitochondrial protection by endogenous antioxidants.

\section{High endogenous antioxidant level attenuates inflammatory response}

To determine whether the mice with enhanced antioxidant ability could reduce inflammatory responses, we measured blood pro-inflammatory cytokine levels. Compared with Lias $^{+/+}{ }^{-L e p r d b / d b}$ mice, IL1 $\beta$ and TNF $\alpha$ levels in Lias High/High Leprdb/db mice were found to be statistically lower $(P<0.05)$ (Table 3). However, statistically, no remarkable difference was seen in serum IL6 level between the two groups (Table 3). The results implied that oxidative stress promotes inflammation in liver steatosis.

\section{Two distinct liver steatosis patterns in the different strains}

Our data showed that both strains of the mice developed NAFLD (Fig. 3A, B, C and D). The steatosis area in the two strains was semi-quantitatively evaluated according to NSCRN scoring criteria. The total score in Lias ${ }^{H i g h / H i g h}$ Leprdb/db $^{2}$

\section{$\operatorname{Lias}^{+/+} \operatorname{Lepr}^{d b / d b}$}
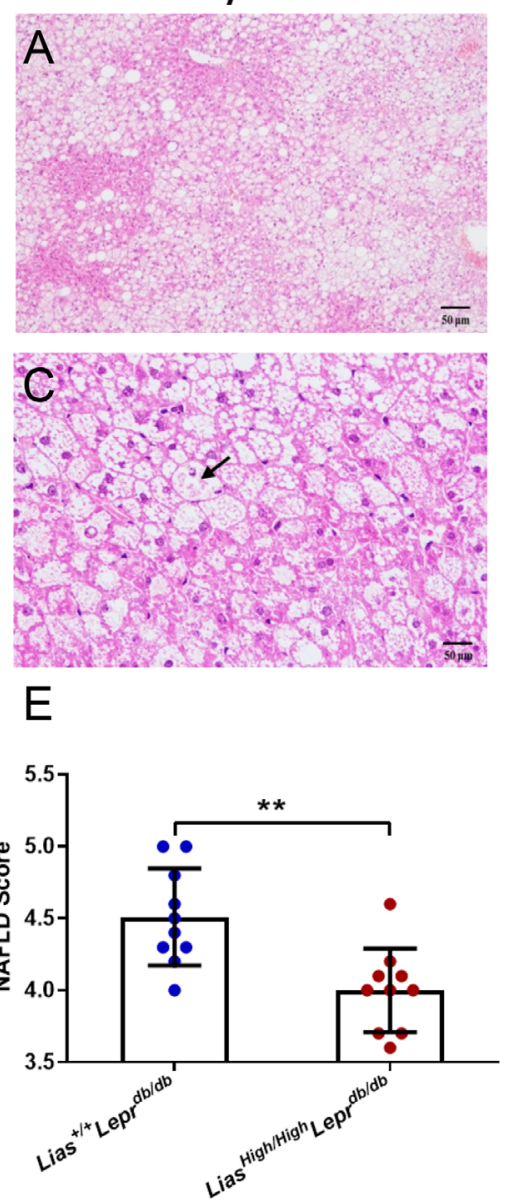

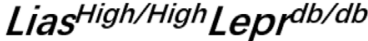
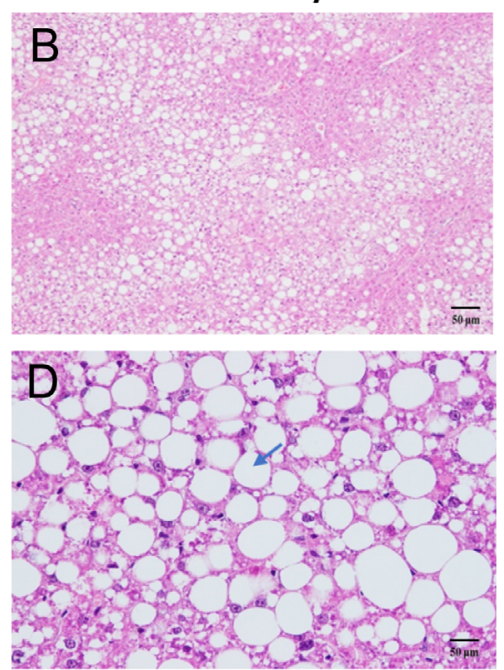

$\mathrm{F}$
Figure 3

Histological patterns of liver steatosis. H\&E staining of representative liver sections in Lias $^{+/+}$Lepr $^{d b / d b}$ mice (A and C) and LiasHigh/High Leprdb/db mice (B and D) at 7-month of age. Original magnification $100 \times$ or $400 \times$. A black arrow indicates areas of macrovesicular and a blue arrowhead points microvesicular steatosis. (E) NAFLD score. (F) Semi-quantitative lipid accumulation degrees and relative abundance of microvesicular and macrovesicular steatosis in LiasHigh/High Leprdb/db and Lias $^{+/+}$Lepr $^{d b / d b}$ mice. Values represent means \pm S.E.M. ${ }^{*} P P<0.01$. 

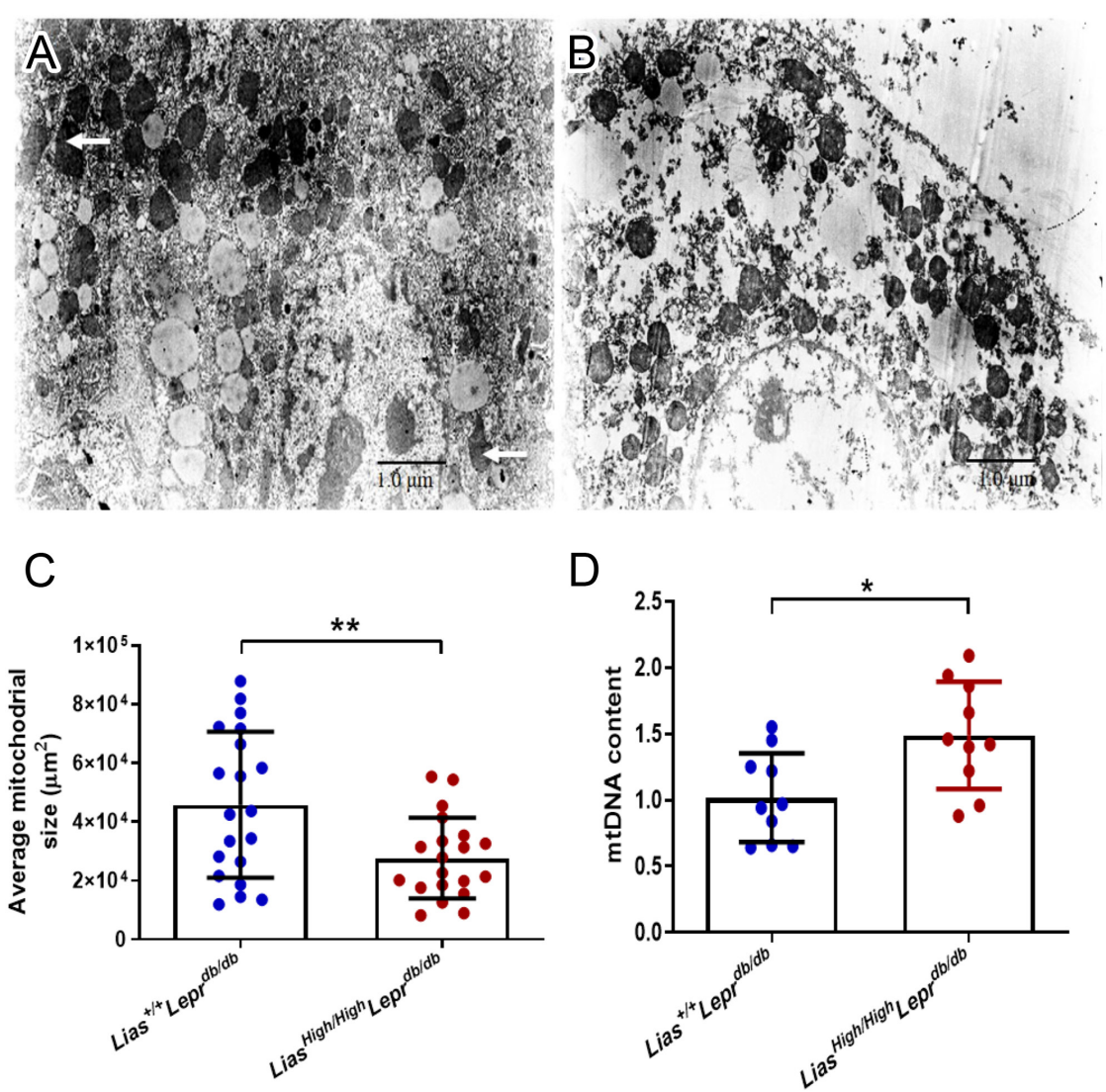

\begin{abstract}
Figure 4
Representative ultrastructural images of mitochondria. Enlarged mitochondria with irregularly shape (white arrows) in Lias ${ }^{+/}$Leprob/db $^{2}$ mice (A). Mitochondria were relatively uniform in size and shape, and enlarged mitochondria were rare in Lias High/lighLeprab/ab mice (B). The average size of mitochondria from six samples per group is presented (C). Levels of mtDNA were measured by real-time fluorescence quantitative PCR (D). Values represent means \pm S.E.M. $* P<0.05$. $\star \star P<0.01$. A full color version of this figure is available at https://doi.org/10.1530/JOE-19-0606.
\end{abstract}

mice was lower in ias $^{+/+}$Lepr $^{d b / d b}$ mice (Fig. 3E). In addition, the percentage of total steatosis area over entire liver area was slightly higher in Lias ${ }^{H i g h / H i g h} L_{e p r}{ }^{d b / d b}$ mice

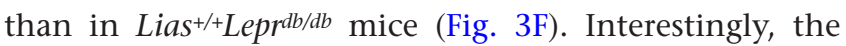
lipid vesicle size and pattern of steatosis were obviously distinct between the two strains. Lias ${ }^{H i g h / H i g h}$ Lepr $^{d b / d b}$ mice predominantly displayed macrovesicular steatosis characterized by a single, large vacuole of fat occupying the cytoplasm and displacing the nucleus to the cell periphery (Fig. 3B and D). On the contrary, Lias ${ }^{+/+}$Lepr $^{d b / d b}$ mouse liver principally exhibited microvesicular steatosis, featured by tiny lipid vesicles leaving the nucleus in the center of the cell and giving the hepatocyte a foamy, spongiocytic appearance (Fig. 3A and C). After semiquantitatively comparing percentage of microvesicular region/entire steatosis region or macrovesicular region/ entire steatosis region, the percentage of two types of steatosis in Lias ${ }^{H i g h / H i g h} L_{e p r d b / d b}$ and Lias $^{+/+}$Lepr $^{d b / d b}$ mice was significantly different $(P<0.01)$ (Fig. 3F). In addition, we found that mitochondrial pleomorphism with increased variability in mitochondrial size and irregular enlargement of mitochondria in $\mathrm{Lias}^{+/+} \mathrm{Lepr}^{\mathrm{db} / \mathrm{db}}$ mice (Fig. 4A). But enlarged mitochondria were rare and the mitochondria were rendered smaller and more uniform in Lias ${ }^{H i g h / H i g h} L_{\text {Lepr }}{ }^{d b / d b}$ mice (Fig. 4B and C). To determine whether the increasing of ATP activity in Lias $^{H i g h / H i g h} L_{\text {eprdb/db }}$ mice (Fig. 2Q) was associated with mitochondrial biogenesis, the copy number of mtDNA, cytochrome $\mathrm{b}$ was measured by real-time PCR. Levels of mtDNA was significantly higher in Lias ${ }^{H i g h / H i g h} L e p r d b / d b$ than Lias $^{+/+}$Leprdb/db mice (Fig. 4D). These data suggest that high endogenous antioxidant capacity protects mitochondria during NAFLD.

\section{Increased endogenous antioxidant activity modulates the gene expression of mitochondrial $\beta$-oxidation and bioenergetics}

In order to further explore the underlying mechanisms of mitochondrial protection by increased endogenous antioxidant capacity during NAFLD, the expression of several key protein and genes associated with mitochondrial $\beta$-oxidation and bioenergetics was evaluated.

Our results showed that NAFLD markedly decreased LIAS protein expression $(P<0.05)$ in liver mitochondrion of Lias $^{+/+} \operatorname{Lepr}^{d b / d b}$ mice, overexpression of Lias gene of Lias $^{\text {High/High Leprdb/db }}$ mice was able to completely offset 
A
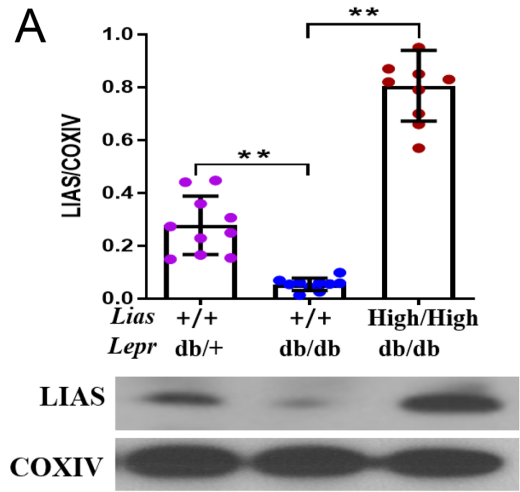

C

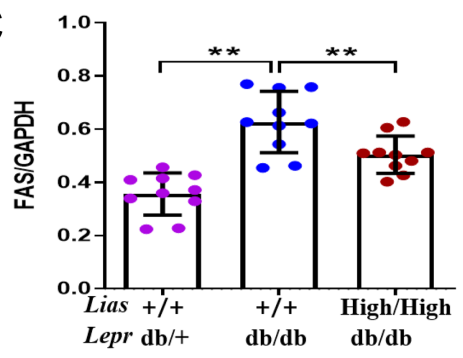

FAS

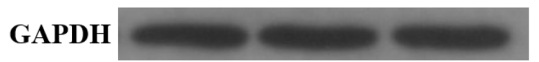

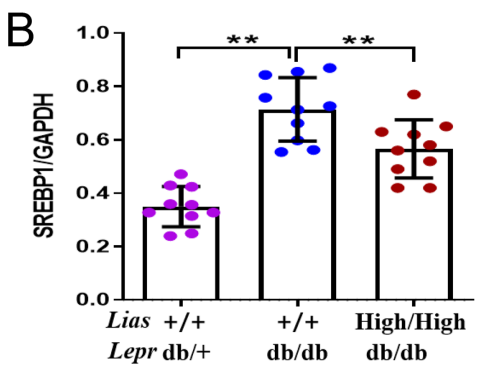
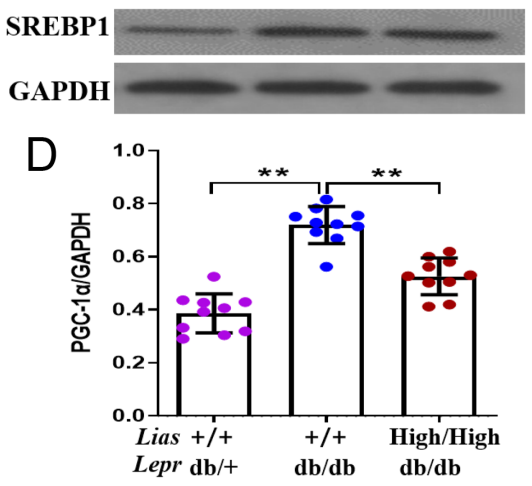

PGC-1a

GAPDH

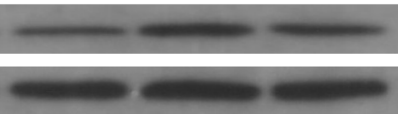

Figure 5

Altered proteins and mRNAs expression levels. The gene expression was measured by Western blotting and qRT-PCR in the liver tissue or liver mitochondria from Lias High/High Leprdb/db mice versus Lias $^{+/+}$Lepr $^{d b / d b}$ mice at 7 months. Lias ${ }^{+/+}$Leprdb/+ $^{d /}$ mice as controls. Expression of LIAS protein levels in mice liver mitochondria (A), SREBP1 protein levels (B), FAS protein levels (C), and PGC- $1 \alpha$ protein levels (D) in mice liver, measured by Western blotting. COX $\square$ or GAPDH served as an internal control for Western blotting. The relative expression of proteins was quantified using Image J Software. (E) q-PCR analysis of PRKaa2, Acads, Cpt1a, Ucp2, Tfam and Sirt 1 mRNA levels in liver tissues. $\beta$-actin served as an internal control for q-PCR. Results were expressed as mean \pm S.E.M. and were compared by one-way ANOVA. $\star P<0.05 ; * * P<0.01$. these effects $(P<0.01)$ (Fig. 5A), and it is further verified that Lias ${ }^{H i g h / H i g h}$ mice have high endogenous antioxidant capacity. The SREBP1, FAS and PGC1 $\alpha$ protein levels

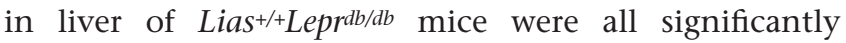
up-regulated compared to Lias ${ }^{+/}$Leprdb/+ mice as the control, overexpression of Lias gene in Lias ${ }^{H i g h / H i g h} L e p r d b / d b$ mice was able to offset these effects $(P<0.05)$, suggesting that increased endogenous antioxidant capacity inhibited the steatosis of mice hepatocytes, inhibited the liver lipid metabolism disorder by NAFLD (Fig. 5B, C and D).

The results showed that NAFLD markedly decreased Cpt1a $(P<0.05)$ and Tfam gene expression $(P<0.05)$

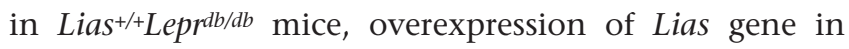
Lias $^{\text {High/High }}$ Lepr $^{\text {db/db }}$ mice was able to completely offset these effects (Fig. 5E), suggesting that increased endogenous antioxidant capacity promoted mitochondrial $\beta$-oxidation and biogenesis. The gene expression of Prkaa2 in Lias $^{+/+}{ }^{2}$ eprdb/db mice was reduced by $75 \%$ compared to Lias $^{+/+}$Lepr $^{d b /+}$ mice as the control, whereas it was increased by $93 \%$ in Lias $^{H i g h / H i g h}$ Lepr $^{d b / d b}$ mice compared

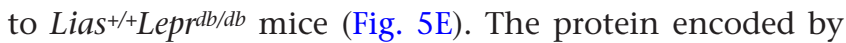
Prkaa2 gene is a catalytic subunit of the AMP-activated protein kinase (AMPK). The data suggested that NAFLD was associated with inhibited AMPK but Lias gene overexpression could partially reverse the activity. Compared with the control, there was a non-significant decrease $(P=0.24)$ in mRNA expression of Ucp2 $(-15 \%)$ in Lias $^{+/+}{ }^{+}$eprdb/db mice, but this decrease was significantly reversed in Lias ${ }^{H i g h / H i g h} L$ epr ${ }^{d b / d b}$ mice $(P<0.01)$ (Fig. 5E). Sirt $I$ gene expression was decreased in $\mathrm{Lias}^{+/+} \mathrm{Lepr}^{\mathrm{db} / \mathrm{db}}$ mouse liver compared to the control and its expression further

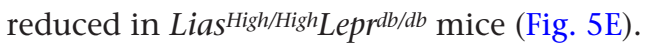




\section{Discussion}

In this study, we intensively investigated the novel mouse model according to criteria for NAFLD patients (Santhekadur et al. 2018). We found that this model resembled many features of human NAFLD, especially for the contribution of mitochondrial dysfunction resulting from oxidative stress to the diseases. Our data clearly demonstrated that oxidative stress played a critical role in the development of NAFLD and that enhanced endogenous antioxidant reservoir significantly attenuated NAFLD in Lias ${ }^{\text {High/HighLeprdb/db mice. }}$

We evaluated hepatic oxidative stress in the mouse model by measuring the multiple antioxidant/oxidative stress biomarkers in plasma and/or liver mitochondria. All of these results indicated that the oxidative stress level was significantly lower and the antioxidant content was significantly higher in Lias ${ }^{H i g h / H i g h}$ Lepr $^{\text {db/db }}$ mice than Lias $^{+/+L e p r d b / d b}$ mice. Thus, our results provide solid evidence to support the role of oxidative stress in the development of NAFLD.

Growing evidence suggests a pivotal role of mitochondrial dysfunction in the development of NASH (Koliaki et al. 2015). We observed that as a consequence of increased mitochondrial antioxidant content, Lias High/HighLeprdb/db mice exhibited milder liver damage. Interestingly, the lipid vesicle size and pattern of steatosis between the two stains were noticeably different. Macrovesicular steatosis is a common form of NAFLD. Unlike microvesicular steatosis, macrovesicular steatosis does not consistently correlate with features of cell injury and steatohepatitis since it rarely progresses to fibrosis or cirrhosis (Contos et al. 2004, Oleszczuk et al. 2007, Tandra et al. 2011). In contrast, the presence of microvesicular steatosis in humans is significantly associated with histological hallmarks of cellular injury (Sherlock 1995), as a result of mitochondrial dysfunction with subsequent impaired $\beta$-oxidation giving rise to liver triglyceride accumulation (Fromenty et al. 1997). In microvesicular steatosis, NEFA is poorly oxidized in mitochondria, resulting in a considerable increase in liver and plasma (Pessayre et al. 1999, Bjorndal et al. 2018). These observations were supported by our finding that plasma NEFA level was significantly lower in Lias ${ }^{H i g h / H i g h} L e p r d b / d b$ mice. Moreover, megamitochondria formation reflects hepatic injury to the mitochondrial electron transport chain in patients (Le et al. 2004), but corresponding ultrastructural change in rodents is mitochondrial swelling (Kirsch et al. 2003), which occurred in Lias ${ }^{+/+}$Lepr $^{\text {db/db }}$ mice. The microvesicular steatosis, co-presence with enlarged mitochondria, may serve as additional histological evidence for mitochondrial dysfunction.

Inflammation is another important factor in mediating the pathogenesis of NAFLD. Elevated levels of pro-inflammatory cytokines and chemokines including IL1 $\beta$, TNF $\alpha$ and MCP1 are found in the different aspects of pathophysiology of human NAFLD/NASH (Singal et al. 2011). They are significantly declined in Lias High/High Leprdb/db mice suggest that elevated endogenous antioxidant ability help suppress inflammation to curb the NAFLD development toward NASH. This is not unexpected since our previous study already demonstrated that LA was able to quench inflammation (Yi et al. 2009).

CPT1 $\alpha, A M P K$ and Tfam gene is downregulated in Lias $^{++}$Lepr $^{d b / d b}$ mice, which partially or entirely offset in Lias ${ }^{H i g h / H i g h}$ Leprdb/db mice. CPT1 $\alpha$ is an enzyme present in the outer mitochondria membrane that regulates $\beta$-oxidation by transferring long-chain fatty acids into the mitochondria (Schreurs et al. 2010). Therefore, we postulated that the anti-adipogenic effect of LA was partially associated with the expression of $\beta$-oxidationrelated genes. AMPK plays an important role in regulating intracellular energy metabolism, and has been identified as a major regulator of mitochondrial biogenesis (Bergeron et al. 2001). The increase in hepatic Tfam mRNA level indicates that elevated endogenous antioxidant induces mitochondrial biogenesis, which may increase the capacities of mitochondrial respiration and lipid $\beta$-oxidation to support ATP production. Additionally, the hepatic mRNA levels of two genes encoding Acads and Sirt1 were either unchanged or decreased in Lias High/High Leprdb/db, compared with Lias $^{+/}{ }^{+}$eprdb/db mice. The results of this study suggest that overexpression of Lias gene does not affect short-chain fatty acid $\beta$-oxidation.

Overall, our new model shares many pathological changes with NAFLD patients, especially oxidative stressderived changes. Overexpression of Lias gene effectively reduces oxidative stress and protects mitochondria, and consequently attenuates NAFLD.

\section{Supplementary materials}

This is linked to the online version of the paper at https://doi.org/10.1530/ JOE-19-0606.

\section{Declaration of interest}

The authors declare that there is no conflict of interest that could be perceived as prejudicing the impartiality of the research reported. 


\section{Funding}

This research was funded by the National Natural Science Foundation of China (81703183 to Guangcui Xu and 81773399 to Yingzheng Zhao) and Scientific and Technological Research Project of Henan Provincial Science and Technology Department (182102310078 to Guangcui Xu).

\section{Author contribution statement}

Yingzheng Zhao and Xianwen $Y i$ involved in the conceptualization of the study. Guangcui Xu, Tingting Yan, Qiang Peng and Haibin Li involved in methodology. Yingzheng Zhao and Weidong Wu contributed to data validation. Guangcui Xu, Tingting Yan, Qiang Peng and Yingzheng Zhao involved in data curation. Guangcui Xu and Yingzheng Zhao contributed to writing - original draft preparation. Xianwen $\mathrm{Yi}$ and Weidong $\mathrm{Wu}$ contributed to writing - review and editing. Yingzheng Zhao and Haibin Li involved in supervision. Weidong Wu contributed to project administration. Xianwen Yi contributed to manuscript submission. All authors have read and agreed to the published version of the manuscript.

\section{Acknowledgements}

The authors thank Xuxu Zhang and Xiaonan Zhai for participation in this study, especially for mouse colony maintenance.

\section{References}

Bergeron R, Ren JM, Cadman KS, Moore IK, Perret P, Pypaert M, Young LH, Semenkovich CF \& Shulman GI 2001 Chronic activation of AMP kinase results in NRF-1 activation and mitochondrial biogenesis. American Journal of Physiology: Endocrinology and Metabolism 281 E1340-E1346. (https://doi.org/10.1152/ajpendo.2001.281.6.E1340)

Bjorndal B, Alteras EK, Lindquist C, Svardal A, Skorve J \& Berge RK 2018 Associations between fatty acid oxidation, hepatic mitochondrial function, and plasma acylcarnitine levels in mice. Nutrition and Metabolism 15 10. (https://doi.org/10.1186/s12986-018-0241-7)

Brunt EM, Janney CG, Di Bisceglie AM, Neuschwander-Tetri BA \& Bacon BR 1999 Nonalcoholic steatohepatitis: a proposal for grading and staging the histological lesions. American Journal of Gastroenterology 94 2467-2474. (https://doi.org/10.1111/j.1572-0241.1999.01377.x)

Caldwell S \& Lackner C 2017 Perspectives on NASH histology: cellular ballooning. Annals of Hepatology 16 182-184. (https://doi. org/10.5604/16652681.1231550)

Caldwell SH, Oelsner DH, Iezzoni JC, Hespenheide EE, Battle EH \& Driscoll CJ 1999 Cryptogenic cirrhosis: clinical characterization and risk factors for underlying disease. Hepatology 29 664-669. (https:// doi.org/10.1002/hep.510290347)

Contos MJ, Choudhury J, Mills AS \& Sanyal AJ 2004 The histologic spectrum of nonalcoholic fatty liver disease. Clinics in Liver Disease $\mathbf{8}$ 481-500, vii. (https://doi.org/10.1016/j.cld.2004.04.013)

Cortez-Pinto H, Chatham J, Chacko VP, Arnold C, Rashid A \& Diehl AM $1999 a$ Alterations in liver ATP homeostasis in human nonalcoholic steatohepatitis: a pilot study. JAMA 282 1659-1664. (https://doi. org/10.1001/jama.282.17.1659)

Cortez-Pinto H, Camilo ME, Baptista A, De Oliveira AG \& De Moura MC $1999 b$ Non-alcoholic fatty liver: another feature of the metabolic syndrome? Clinical Nutrition 18 353-358. (https://doi.org/10.1016/ s0261-5614(99)80015-6)

Cosma A, Cecchet D, Gaiani S, Coracina A, Pellizzari P, Pizzi C, Veronese N, Sacerdoti D \& Tessari P 2015 Clinical and biochemical determinants of the extent of liver steatosis in type 2 diabetes mellitus. European Journal of Gastroenterology and Hepatology $\mathbf{2 7}$ 1386-1391. (https://doi.org/10.1097/MEG.0000000000000462)

Day CP \& James OF 1998 Steatohepatitis: a tale of two 'hits'? Gastroenterology 114 842-845. (https://doi.org/10.1016/s00165085(98)70599-2)

deGoma EM, deGoma RL \& Rader DJ 2008 Beyond high-density lipoprotein cholesterol levels evaluating high-density lipoprotein function as influenced by novel therapeutic approaches. Journal of the American College of Cardiology 51 2199-2211. (https://doi. org/10.1016/j.jacc.2008.03.016)

Dorsam B \& Fahrer J 2016 The disulfide compound alpha-lipoic acid and its derivatives: a novel class of anticancer agents targeting mitochondria. Cancer Letters 371 12-19. (https://doi.org/10.1016/j. canlet.2015.11.019)

Filozof C, Goldstein BJ, Williams RN \& Sanyal A 2015 Non-alcoholic steatohepatitis: limited available treatment options but promising drugs in development and recent progress towards a regulatory approval pathway. Drugs 75 1373-1392. (https://doi.org/10.1007/ s40265-015-0437-3)

Folch J, Lees M \& Sloane Stanley GH 1957 A simple method for the isolation and purification of total lipides from animal tissues. Journal of Biological Chemistry 226 497-509.

Franzen LE, Ekstedt M, Kechagias S \& Bodin L 2005 Semiquantitative evaluation overestimates the degree of steatosis in liver biopsies: a comparison to stereological point counting. Modern Pathology 18 912-916. (https://doi.org/10.1038/modpathol.3800370)

Fromenty B, Berson A \& Pessayre D 1997 Microvesicular steatosis and steatohepatitis: role of mitochondrial dysfunction and lipid peroxidation. Journal of Hepatology 26 (Supplement 1) 13-22. (https:// doi.org/10.1016/s0168-8278(97)82328-8)

Groenbaek K, Friis H, Hansen M, Ring-Larsen H \& Krarup HB 2006 The effect of antioxidant supplementation on hepatitis $C$ viral load, transaminases and oxidative status: a randomized trial among chronic hepatitis C virus-infected patients. European Journal of Gastroenterology and Hepatology 18 985-989. (https://doi.org/10.1097/01. meg.0000231746.76136.4a)

Ka SO, Bang IH, Bae EJ \& Park BH 2017 Hepatocyte-specific sirtuin 6 deletion predisposes to nonalcoholic steatohepatitis by up-regulation of Bach1, an Nrf2 repressor. FASEB Journal 31 3999-4010. (https://doi. org/10.1096/fj.201700098RR)

Kirsch R, Clarkson V, Shephard EG, Marais DA, Jaffer MA, Woodburne VE, Kirsch RE \& Hall PdeL 2003 Rodent nutritional model of nonalcoholic steatohepatitis: species, strain and sex difference studies. Journal of Gastroenterology and Hepatology 18 1272-1282. (https://doi. org/10.1046/j.1440-1746.2003.03198.x)

Kleiner DE, Brunt EM, Van Natta M, Behling C, Contos MJ, Cummings OW, Ferrell LD, Liu YC, Torbenson MS, Unalp-Arida A, et al. 2005 Design and validation of a histological scoring system for nonalcoholic fatty liver disease. Hepatology 41 1313-1321. (https:// doi.org/10.1002/hep.20701)

Koliaki C, Szendroedi J, Kaul K, Jelenik T, Nowotny P, Jankowiak F, Herder C, Carstensen M, Krausch M, Knoefel WT, et al. 2015 Adaptation of hepatic mitochondrial function in humans with non-alcoholic fatty liver is lost in steatohepatitis. Cell Metabolism 21 739-746. (https://doi.org/10.1016/j.cmet.2015.04.004)

Le TH, Caldwell SH, Redick JA, Sheppard BL, Davis CA, Arseneau KO, Iezzoni JC, Hespenheide EE, Al-Osaimi A \& Peterson TC 2004 The zonal distribution of megamitochondria with crystalline inclusions in nonalcoholic steatohepatitis. Hepatology 39 1423-1429. (https://doi. org/10.1002/hep.20202)

Lindquist C, Bjorndal B, Rossmann CR, Svardal A, Hallstrom S \& Berge RK 2018 A fatty acid analogue targeting mitochondria exerts a plasma triacylglycerol lowering effect in rats with impaired carnitine biosynthesis. PLoS ONE 13 e0194978. (https://doi.org/10.1371/ journal.pone.0194978) https://joe.bioscientifica.com https://doi.org/10.1530/JOE-19-0606 (c) 2021 Society for Endocrinology Published by Bioscientifica Ltd. Printed in Great Britain 
Liu J 2008 The effects and mechanisms of mitochondrial nutrient alphalipoic acid on improving age-associated mitochondrial and cognitive dysfunction: an overview. Neurochemical Research 33 194-203. (https://doi.org/10.1007/s11064-007-9403-0)

Mansouri A, Gaou I, Fromenty B, Berson A, Letteron P, Degott C, Erlinger S \& Pessayre D 1997 Premature oxidative aging of hepatic mitochondrial DNA in Wilson's disease. Gastroenterology 113 599-605. (https://doi.org/10.1053/gast.1997.v113.pm9247482)

Namazi N, Larijani B \& Azadbakht L 2018 Alpha-lipoic acid supplement in obesity treatment: a systematic review and meta-analysis of clinical trials. Clinical Nutrition 37 419-428. (https://doi.org/10.1016/j. clnu.2017.06.002)

Oleszczuk A, Spannbauer M, Tannapfel A, Bluher M, Hengstler J, Pietsch UC, Schuhmacher A, Wittekind C, Hauss JP \& Schon MR 2007 Regenerative capacity differs between micro- and macrovesicular hepatic steatosis. Experimental and Toxicologic Pathology 59 205-213. (https://doi.org/10.1016/j.etp.2007.05.009)

Pais R, Barritt ASt, Calmus Y, Scatton O, Runge T, Lebray P, Poynard T, Ratziu V \& Conti F 2016 NAFLD and liver transplantation: current burden and expected challenges. Journal of Hepatology 65 1245-1257. (https://doi.org/10.1016/j.jhep.2016.07.033)

Pamuk GE \& Sonsuz A 2003 N-acetylcysteine in the treatment of nonalcoholic steatohepatitis. Journal of Gastroenterology and Hepatology 18 1220-1221. (https://doi.org/10.1046/j.1440-1746.2003.03156.x)

Park KG, Min AK, Koh EH, Kim HS, Kim MO, Park HS, Kim YD, Yoon TS, Jang BK, Hwang JS, et al. 2008 Alpha-lipoic acid decreases hepatic lipogenesis through adenosine monophosphate-activated protein kinase (AMPK)-dependent and AMPK-independent pathways. Hepatology 48 1477-1486. (https://doi.org/10.1002/hep.22496)

Pessayre D, Mansouri A, Haouzi D \& Fromenty B 1999 Hepatotoxicity due to mitochondrial dysfunction. Cell Biology and Toxicology 15 367-373. (https://doi.org/10.1023/a:1007649815992)

Rogers GW, Brand MD, Petrosyan S, Ashok D, Elorza AA, Ferrick DA \& Murphy AN 2011 High throughput microplate respiratory measurements using minimal quantities of isolated mitochondria. PLOS ONE 6 e21746. (https://doi.org/10.1371/journal.pone.0021746)

Sahai A, Malladi P, Pan X, Paul R, Melin-Aldana H, Green RM \& Whitington PF 2004 Obese and diabetic db/db mice develop marked liver fibrosis in a model of nonalcoholic steatohepatitis: role of shortform leptin receptors and osteopontin. American Journal of Physiology: Gastrointestinal and Liver Physiology 287 G1035-G1043. (https://doi. org/10.1152/ajpgi.00199.2004)

Santhekadur PK, Kumar DP \& Sanyal AJ 2018 Preclinical models of nonalcoholic fatty liver disease. Journal of Hepatology $\mathbf{6 8} 230-237$. (https:// doi.org/10.1016/j.jhep.2017.10.031)

Sanyal AJ, Chalasani N, Kowdley KV, McCullough A, Diehl AM, Bass NM, Neuschwander-Tetri BA, Lavine JE, Tonascia J, Unalp A, et al. 2010 Pioglitazone, vitamin E, or placebo for nonalcoholic steatohepatitis. New England Journal of Medicine 362 1675-1685. (https://doi. org/10.1056/NEJMoa0907929)

Schreurs M, Kuipers F \& van der Leij FR 2010 Regulatory enzymes of mitochondrial beta-oxidation as targets for treatment of the metabolic syndrome. Obesity Reviews 11 380-388. (https://doi. org/10.1111/j.1467-789X.2009.00642.x)

Serviddio G, Bellanti F, Tamborra R, Rollo T, Capitanio N, Romano AD, Sastre J, Vendemiale G \& Altomare E 2008 Uncoupling protein-2 (UCP2) induces mitochondrial proton leak and increases susceptibility of non-alcoholic steatohepatitis (NASH) liver to ischaemia-reperfusion injury. Gut 57 957-965. (https://doi. org/10.1136/gut.2007.147496)
Sherlock S 1995 Alcoholic liver disease. Lancet 345 227-229. (https://doi. org/10.1016/s0140-6736(95)90226-0)

Singal AK, Jampana SC \& Weinman SA 2011 Antioxidants as therapeutic agents for liver disease. Liver International 31 1432-1448. (https://doi org/10.1111/j.1478-3231.2011.02604.x)

Solis-Munoz P, Solis-Herruzo JA, Fernandez-Moreira D, GomezIzquierdo E, Garcia-Consuegra I, Munoz-Yague T \& Garcia Ruiz I 2011 Melatonin improves mitochondrial respiratory chain activity and liver morphology in ob/ob mice. Journal of Pineal Research $\mathbf{5 1}$ 113-123. (https://doi.org/10.1111/j.1600-079X.2011.00868.x)

Takahashi Y 2012 Essential roles of growth hormone (GH) and insulinlike growth factor-I (IGF-I) in the liver. Endocrine Journal 59 955-962. (https://doi.org/10.1507/endocrj.ej12-0322)

Tanaka Y, Kaibori M, Miki H, Nakatake R, Tokuhara K, Nishizawa M, Okumura T \& Kwon AH 2015 Alpha-lipoic acid exerts a liverprotective effect in acute liver injury rats. Journal of Surgical Research 193 675-683. (https://doi.org/10.1016/j.jss.2014.08.057)

Tandra S, Yeh MM, Brunt EM, Vuppalanchi R, Cummings OW, UnalpArida A, Wilson LA \& Chalasani N 2011 Presence and significance of microvesicular steatosis in nonalcoholic fatty liver disease. Journal of Hepatology 55 654-659. (https://doi.org/10.1016/j.jhep.2010.11.021)

Vajro P, Mandato C, Franzese A, Ciccimarra E, Lucariello S, Savoia M, Capuano G \& Migliaro F 2004 Vitamin E treatment in pediatric obesity-related liver disease: a randomized study. Journal of Pediatric Gastroenterology and Nutrition 38 48-55. (https://doi. org/10.1097/00005176-200401000-00012)

Wong VW \& Wong GL 2016 A LEAN treatment for non-alcoholic steatohepatitis. Lancet 387 628-630. (https://doi.org/10.1016/S01406736(15)00982-4)

Wortham M, He L, Gyamfi M, Copple BL \& Wan YJ 2008 The transition from fatty liver to NASH associates with SAMe depletion in $\mathrm{db} / \mathrm{db}$ mice fed a methionine choline-deficient diet. Digestive Diseases and Sciences 53 2761-2774. (https://doi.org/10.1007/s10620-007-0193-7)

Xu L, Hiller S, Simington S, Nickeleit V, Maeda N, James LR \& Yi X 2016 Influence of different levels of lipoic acid synthase gene expression on diabetic nephropathy. PLOS ONE 11 e0163208. (https://doi. org/10.1371/journal.pone.0163208)

Yi X \& Maeda N 2005 Endogenous production of lipoic acid is essential for mouse development. Molecular and Cellular Biology 25 8387-8392. (https://doi.org/10.1128/МСB.25.18.8387-8392.2005)

Yi X \& Maeda N 2006 Alpha-lipoic acid prevents the increase in atherosclerosis induced by diabetes in apolipoprotein E-deficient mice fed high-fat/low-cholesterol diet. Diabetes 55 2238-2244. (https://doi. org/10.2337/db06-0251)

Yi X, Kim K, Yuan W, Xu L, Kim HS, Homeister JW, Key NS \& Maeda N 2009 Mice with heterozygous deficiency of lipoic acid synthase have an increased sensitivity to lipopolysaccharide-induced tissue injury. Journal of Leukocyte Biology 85 146-153. (https://doi.org/10.1189/ jlb.0308161)

Yi X, Xu L, Hiller S, Kim HS \& Maeda N 2012 Reduced alpha-lipoic acid synthase gene expression exacerbates atherosclerosis in diabetic apolipoprotein E-deficient mice. Atherosclerosis 223 137-143. (https:// doi.org/10.1016/j.atherosclerosis.2012.04.025)

Yki-Jarvinen H 2014 Non-alcoholic fatty liver disease as a cause and a consequence of metabolic syndrome. Lancet: Diabetes and Endocrinology 2 901-910. (https://doi.org/10.1016/S2213-8587(14)70032-4)

Younossi ZM, Koenig AB, Abdelatif D, Fazel Y, Henry L \& Wymer M 2016 Global epidemiology of nonalcoholic fatty liver disease-Meta-analytic assessment of prevalence, incidence, and outcomes. Hepatology 64 73-84. (https://doi.org/10.1002/hep.28431)

Received in final form 23 October 2020

Accepted 24 November 2020

Accepted Manuscript published online 1 December 2020 https://joe.bioscientifica.com https://doi.org/10.1530/JOE-19-0606 (c) 2021 Society for Endocrinology Published by Bioscientifica Ltd. Printed in Great Britain 